\title{
EMERGING METRONIDAZOLE RESISTANCE IN ANAEROBES AND MAPPING THEIR SUSCEPTIBILITY BEHAVIOUR
}

\author{
Manu Chaudhary and Anurag Payasi \\ Venus Medicine Research Centre, Hill Top Industrial Estate, Bhatoli Kalan, Baddi, H.P.-173205 India
}

Received 2014-02-26; Received 2014-04-07; Accepted 2014-04-12

\begin{abstract}
In the present study, anaerobic clinical isolates of Bacteroides fragilis, Escherichia coli, Staphylococcus aureus and Yersinia enterocolitica were obtained from different clinical specimens and were subjected to molecular typing to detect the gene encoding metronidazole resistance in these isolates. Subsequently, antibacterial activity of drugs was tested against the selected clinical isolates. A total of 53 clinical isolates involving 18 obligate and 35 facultative anaerobic bacteria were recovered from clinical samples of 67 patients who were suspected to have anaerobic infection. A disk diffusion method was employed to screen for metronidazole-resistance among these isolates. PCR assay was used to detect the metronidazole resistant gene ( $\mathrm{nim}$ ). Susceptibility studies in metronidazole resistant clinical isolates as well as positive controls were performed according to Clinical and Laboratory Standards Institute (CLSI) guidelines. According to disc diffusion method, of 53 isolates, 21 isolates (39.6\%) were found to be metronidazole resistant. Further screening of these isolates with PCR revealed only 13 isolates $(24.5 \%)$ carry nim gene. Out of which 7 were of $B$. fragilis, 3 were of $Y$. enterocolitica, 2 were of $E$. coli and 1 was of $S$. aureus. The highest number of metronidazole resistant isolates were found in abscess (7) followed by intra-abdominal infection (5) and bone and joint infection (1). When metronidazole resistant isolates were subjected to screen for the presence of nim gene, all isolates were found to carry nim gene. According to minimum inhibitory concentration (MIC) data, among the tested antibacterial agents, Mebatic emerged as the most active antibacterial against metronidazole resistant isolates of B. fragilis, E. coli, S. aureus and Y. enterocolitica with MIC values 0.125 to $1.0 \mu \mathrm{g} \mathrm{mL}^{-1}$. Similarly, Antimicrobial Susceptibility Test (AST) data also revealed that Mebatic was most efficacious in the metronidazole resistant organisms. From the above results, it is evident that Mebatic has enhanced in vitro antibacterial activity compared to other drugs in metronidazole resistant isolates thus can be a potent antibacterial agent for the treatment of infections caused by metronidazole resistant organisms.
\end{abstract}

Keywords: Anaerobes, Resistance, Clinical Isolates, Metronidazole, Mebatic, Nim Gene

\section{INTRODUCTION}

Obligate and facultative anaerobic bacteria are a common causes of infections, some of which can be serious and life-threatening. Bacteroides species are an important opportunist obligate anaerobic pathogens that are commonly isolated from human polymicrobial infections. Some common pathogenic facultative anaerobic bacteria include Staphylococcus spp., Streptococcus spp., Shigella, Yertinia enterocolitica and Escherichia coli (Gaetti-Jardim et al., 2010; Guss et al., 2011). Among the Bacteroides species, Bacteroides fragilis group is the most prevalent organism accounting for 41 to $78 \%$ of the isolates of this group. B. fragilis constitute major part of gastrointestinal flora (Brook, 2008) but comprising least common Bacteroides occur in Corresponding Author: Anurag Payasi, Venus Medicine Research Centre, Hill Top Industrial Estate, Bhatoli Kalan, Baddi, H.P.-173205 India Tel: 91-1795-302068 Fax: 91-1795-302133 
fecal flora accounting only $0.5 \%$ of the bacteria present in stool. Obligate and facultative anaerobic bacteria have been reported to be involved in peritoneal infections (Levinson, 2010), bacteremia (Brook, 2010) intraabdominal infections, diarrhea (Merino et al., 2011) and subcutaneous abscesses or burns near the anus (Brook, 2008). The pathogenicity of these groups of organisms is mainly due to capsular polysaccharide which makes it protective against phagocytosis (Levinson, 2010).

Apart from Metronidazole which has been the drug of choice for the treatment of infections caused by anaerobic bacteria across the world for nearly 40 years (Cohen et al., 2010), anaerobic microbes show sensitivity to carbapenems, tigecycline, beta-lactam and beta-lactamase inhibitor combinations. However, in the past few years, metronidazole resistance among obligate anaerobes is a matter of concern as intermediate or highlevel resistance to metronidazole have been reported (Alauzet et al., 2010). These species can also be resistant to a number of other antimicrobial agents such as beta-lactam agents (imipenem and cefoxitin), tetracycline and clindamycin (Boente et al., 2010; Nakano et al., 2011). Metronidazole resistance has been reported in Europe (Nagy et al., 2011; Hartmeyer et al., 2012), United states of America (USA) (Schapiro et al., 2004) and Africa (Buta et al., 2010).

It has been observed that resistance to beta-lactams in obligate and facultative anaerobic organisms is maily associated with Extended Spectrum Beta Lactamase (ESBL) and Metallo Beta Lactamse (MBL) production (Snydman et al., 2010). Whereas mechanism for metronidazole resistance in $B$. fragilis include the presence of nim genes, which encode 5nitroimidazole reductases that convert metronidazole to a non-toxic amino derivative (Pumbwe et al., 2008), overexpression of the DNA repair protein, RecA (Steffens et al., 2010) and disruption of the electron transport chain (Lynch et al., 2013). 5nitroimidazole resistance genes, $\operatorname{nim} A$ to $E$, have been identified to confer reduced susceptibility to 5nitroimidazole antibiotics on species of the $B$. fragilis group (Hartmeyer et al., 2012). The nim genes encode a 5-nitroimidazole reductase (Nagy et al., 2011).

A very few data exist on the susceptibility of obligate and facultative organisms to antimicrobial agents commonly used for eradication of these pathogens. The reports of acquisition of metronidazole resistance by $B$. fragilis from India emphasizes the need for a study to assess more accurately the susceptibility profile of clinical isolates of obligate and facultative anaerobic organisms. Since antimicrobial resistance in anaerobes varies from one hospital to another and between different geographic locations, all hospitals must survey their sensitivity patterns and report any emerging resistance. Unfortunately, most of the Indian hospitals are ill equiped for anerobes culture, hence detection of anerobic resistance becomes even a more challanging issue.

This study involved screening of the presence of nim gene in clinical isolates collected from various hospitals of India and to study susceptibility of commonly used antibacterial agents against these nim positive isolates.

\section{MATERIALS AND METHODS}

\subsection{Samples Collection}

A total of 53 (18 obligate and 35 facultative) anaerobic bacterial isolates were obtained from various clinical samples of 67 patients who are suspected to have anaerobe infection and have been hospitalized in various hospitals of India (The name of hospitals can not be disclosed due to confidential agreement). The isolates were identified as: B. fragilis $(\mathrm{n}=18)$, Escherichia coli $(\mathrm{n}=17)$, Staphylococcus aureus $(\mathrm{n}=11)$, Yersinia enterocolitica $(\mathrm{n}=7)$. All the samples were collected with aseptic precautions from intra-abodominal infection, absess and bone and joint infections. The clinical specimens were taken into Hi-Media Anaerobe Transport Medium and have been delivered to the Venus Medicine Research Center, Baddi, Himachal Pradesh, India, at the shortest possible time. Subsequently, specimens were cultured in BBL CDC Anaerobe 5\% Sheep Blood Agar plates (Becton, Dickinson, USA). Plates were incubated at $37^{\circ} \mathrm{C}$ for $48 \mathrm{~h}$.

Clinical isolates were identified to species level using Vitek 2 system (BioMe'rieux, Marcy, France).

All these isolates were stored at $80^{\circ} \mathrm{C}$ and were cultured on an-aerobic agar medium (Hi-Media, Mumbai, India) supplemented with $6 \%$ horse blood in an anaerobic atmosphere $\left[10 \mathrm{CO}_{2}, 10 \mathrm{H} 2,80 \% \mathrm{~N} 2(\mathrm{v} / \mathrm{v})\right]$ at $37^{\circ} \mathrm{C}$. B. fragilis ATCC 25285 was included as a control organism. Organism collection, transport, confirmation of organism identification and development and management of a centralized database were coordinated by Venus Medicine Research Centre (VMRC), Baddi, India in assistance with Emerging Antimicrobial Resistance Society (EARS).

\subsection{Antibacterial Agents}

The following antibacterial agents were used in this study: Ofloxacin+ornidazole (Mebatic, a novel antibiotic adjuvant entity, Venus Remedies Limited, Panchkula, Haryana, India), ofloxacin (Oflonir, Aishwarya Healthcare, Mumbai, India), ornidazole (Nidazole, Sipra Remedies, Mumbai India), metronidazole 
(Ivmetro, Torrent Pharmaceuticals Limited, Ahmedabad, Gujarat) and ciprofloxacin (Alcipro, Alkem Laboratories Limited, Mumbai, India).

\subsection{Screening of Clinical Isolates for Metronidazole Resistance}

Initial determination of the metronidazole susceptibility of each isolate was carried out by a standard disc diffusion test on CDC Anaerobe 5\% Sheep Blood Agar plates with a $5 \mathrm{mg}$ metronidazole disc (Hi-Media, Mumbai, India).

\subsection{Preparation of Nitroreductase Extract}

Overnight grown cultures were centrifuged at $5000 \mathrm{rpm}$ for $4 \mathrm{~min}$. The pellet was weighed and equal amount of lysozyme was added and then pellet was suspended in phosphate buffer saline (PBS; $10 \mathrm{mM}, \mathrm{pH} 7.4$ ) in order to disrupt bacterial cells. The solution was incubated at $37 \pm 2^{\circ} \mathrm{C}$ for $2 \mathrm{~h}$ and then centrifuged at $7000 \mathrm{rpm}$ for 10 min. The supernatant (crude extracts) was use as a source of enzyme and stored at $-70^{\circ} \mathrm{C}$ until use.

\subsection{Nitroreductase Enzyme Assay}

The nitroreductase enzyme assay was carried out according to the method described by Pal et al. (2009). The reaction mixture comprised of Tris-acetate (100 $\mathrm{mM}$ Tris-HCl, $50 \mathrm{mM}$ acetate buffer, $\mathrm{pH} 7.0), 30 \mu \mathrm{M}$ metronidazole as a substrate, half MIC of different drugs as inhibitors, $0.3 \mathrm{mM}$ NADPH or NADH and enzyme in a $1 \mathrm{~mL}$ reaction volume. The assay was carried out at $25^{\circ} \mathrm{C}$ in a UV-visible spectrophotometer (Shimadzu, Japan) in quartz cuvettes with a $1-\mathrm{cm}$ path length. The results of the assay were determined by measurement of the oxidation of NADPH or NADH at $340 \mathrm{~nm}\left(\mathrm{E} 6.22 \mathrm{mM}^{-1} \mathrm{~cm}^{-1}\right)$.

\subsection{Deoxyribo Necleic Acid (DNA) Isolation}

DNA from all metronidazole isolates was extracted according to the method described by Atashpaz et al., (2010). Five ml of overnight anaerobic grown bacterial culture was used for the DNA isolation. DNA purity and concentrations were measured with spectrophotometer $(260 / 280)$.

\subsection{Polymerase Chain Reaction (PCR)}

The nim gene was detected using previously reported primer (Verma et al., 2012). Primers were synthesized from Sigma Aldrich Chemicals Private Limited, Bangalore, India. Primers used for amplification were nimF-5'- ATGTTCAGAGAAATGCGGCGTAAGCG-3 and nim-R-5'-GCTTCCTTGCCTGTCATGTGCTC-3' that amplify a fragment of about $458 \mathrm{bp}$. PCR amplification was performed in a total volume of $20 \mu \mathrm{L}$ containing $200 \mathrm{pg}$ of DNA, $0.5 \mathrm{mM}$ of dNTPs, $1.25 \mu \mathrm{M}$ of each primer and 1.5 $\mathrm{U}$ of Taq polymerase (Banglore Genei). PCR amplification was carried out on a Eppendorf thermocycler (Germany) with cycling conditions: Initial denaturation at $96^{\circ} \mathrm{C}$ for $5 \mathrm{~min}$ followed by 32 cycles each of denaturation $\left(94^{\circ} \mathrm{C}\right.$ for $\left.60 \mathrm{sec}\right)$, annealing $\left(52^{\circ} \mathrm{C}\right.$ for $120 \mathrm{sec})$, extension $\left(72^{\circ} \mathrm{C}\right.$ for $\left.120 \mathrm{sec}\right)$ and final extension $\left(72^{\circ} \mathrm{C}\right.$ for $\left.7 \mathrm{~min}\right)$, for the amplification of $\mathrm{nim}$ gene. After amplification, PCR products were separated on a $1 \%(\mathrm{w} / \mathrm{v})$ agarose gel containing $25 \mu \mathrm{g}$ of ethidium bromide in Tris-EDTA buffer and the gel was photographed under ultraviolet illumination using gel documentation system (Bio-Rad, USA). A 100-bp DNA ladder (GeNei, Banglore, India) was included in each run. PCR products from control strains $B$. fragilis 638R (kindly gifted by Dr. ND Chaurasiya, National Center for Natural Products Research, Research Institute of Pharmaceutical Sciences, School of Pharmacy, University of Mississippi, University, MS, USA) was used as references for nim gene sizing analysis. The presence of an amplicon of 458 bp were considered as presumptive positive.

\subsection{Determination of Minimum Inhibitory Concentrations (MICs)}

MICs were determined by agar dilution method according to the Clinical and Laboratory Standards Institute (CLSI) guidelines (CLSI, 2013) using the test organism at a concentration of $2 \times 10^{6} \mathrm{cfu} \mathrm{mL}^{-1}$. B. fragilis ATCC25285 was used as reference strain.

\subsection{Determination of Antimicrobial Susceptibility (AST) by Cup Plate Method}

The cup-plate agar diffusion method, a modification described by chaudhary et al. (2012), was adopted to assess the antimicrobial susceptibility of the selected drugs. Inoculum containing $10^{6} \mathrm{cfu}$ $\mathrm{mL}^{-1}$ of test strain was spread with a sterile swab on a petri dish containing CDC blood agar plates and the cups were made in the agar plate using a sterile cork borer $(6.5 \mathrm{~mm})$. Then, $30 \mu \mathrm{L}$ of the drug preparation was placed in the wells using a micro-pipette. The plates were incubated in an anaerobic atmosphere [10 $\left.\mathrm{CO}_{2}, 10 \mathrm{H} 2,80 \mathrm{~N} 2(\mathrm{v} / \mathrm{v})\right]$ at $37^{\circ} \mathrm{C}$ for $48 \mathrm{~h}$. After incubation the zone of inhibition around the wells was measured in $\mathrm{mm}$ (millimeter), averaged and the mean values were recorded. 


\section{RESULTS}

\subsection{Identification of Clinical Isolates}

All of the clinical isolates obtained from various clinical specimens were identified to be B. fragilis (18), E. coli (17), S. aureus (11) and Y. enterocolitica (7) based on their morphological and biochemical characterization. Our data showed the highest number of $B$. fragilis isolates were recovered from intra-abdominal infection (9) followed by abscess (7) and bone and joint infection (2). For $E$. coli, the greatest number of isolates were recovered from intra-abdominal infection (9) followed by abscess (8). Of $11 \mathrm{~S}$. aureus isolates, 6 were obtained from bone and joint infections and 5 were from abscess. $Y$. enterocolitica was only recovered from intraabdominal infection. Overall, the greatest number of isolates were recovered from intra-abdominal $(25 ; 47.1 \%)$, followed by abscess $(20 ; 37.7 \%)$ and bone and joint infections (8; $15.1 \%$ ). When all of these 53 isolates were subjected for selection of metronidazole resistance by disc diffusion method, 21 isolates (39.6\%) were found to be metronidazole resistant. When these metronidazole resistant isolates were subjected to PCR to screen for the presence of nim gene, only 13 isolates were confirmed to be positive with nim gene. Of which 7 were of $B$. fragilis, 3 were of $Y$. enterocolitica, 2 were of $E$. coli and 1 was of $S$. aureus (Table 1 and Fig. 1). The highest number of metronidazole resistant isolates were found in abscess (7) followed by intra-abdominal infection (5) and bone and joint infection (1). The nim gene positive isolates were used for further study.

\subsection{Nitroreductase Enzyme Assay}

The effect of all selected drugs on nitroreductase enzyme inhibition was determined and results showed that Mebatic brought about 86 to $89 \%$ inhibition in nitroreductase activity whereas other comparator drugs produced only 7 to $10 \%$ inhibition (Table 2).

\subsection{MIC}

As shown in the Table 3, Mebatic emerged as the most active antibacterial against metronidazole resistant facultative and obligate anaerobic isolates of $B$. fragilis, E. coli, S. aureus and $Y$. enterocolitica with MIC values 0.125 to $1.0 \mu \mathrm{g} \mathrm{mL}^{-1}$. Ofloxacin was found to be second most active antibacterial agent with MIC values 1 to 8 $\mu \mathrm{g} \mathrm{mL} \mathrm{m}^{-1}$ for $E$. coli, S. aureus and $Y$. enterocolitica whereas MIC for B. fragilis was 8 to $128 \mu \mathrm{g} \mathrm{mL}^{-1}$. The MIC values for ciprofloxacin against $E$. coli and $S$. aureus was 2 to $16 \mu \mathrm{g} \mathrm{mL}^{-1}$ and 2 to $32 \mu \mathrm{g} \mathrm{mL}^{-1}$ and 8 to $128 \mu \mathrm{g} \mathrm{mL}^{-1}$ were observed for $Y$. enterocolitica and $B$. fragilis, respectively. Ornidazole MIC values for was 8 to $64 \mu \mathrm{g} \mathrm{mL}^{-1}$ for $B$. fragilis and S. aureus and 8 to 128 $\mu \mathrm{g} \mathrm{mL}$ for E. coli and $Y$. enterocolitica. The metronidazole MIC values for $B$. fragilis was 8 to $64 \mu \mathrm{g}$ $\mathrm{mL}^{-1}$ whereas 16 to $128 \mu \mathrm{g} \mathrm{mL}^{-1}$ for $S$. aureus and 16 to $128 \mu \mathrm{g} \mathrm{mL}^{-1}$ for E. coli and Y. enterocolitica.

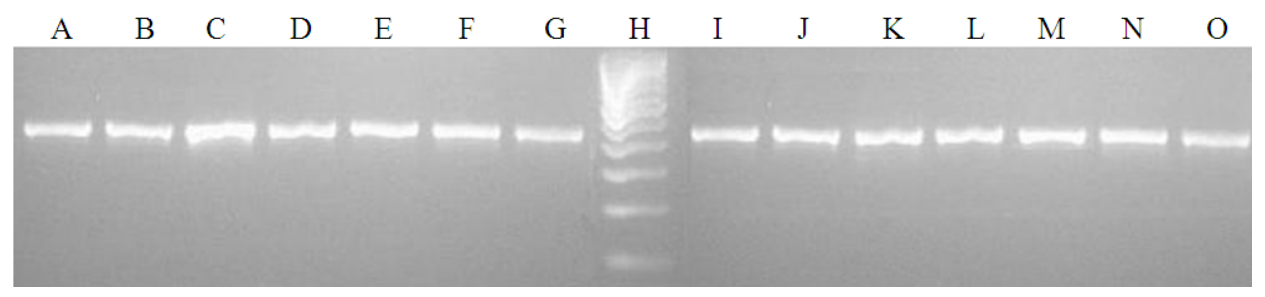

Fig. 1. Agarose gel showing PCR amplified products of nim gene in clinical isolates. Lane H 100 bp DNA size marker; Lane A to G and I to N nim (458 bp); lane O nim Positive control B. fragilis 638R (458 bp)

Table 1. Source of clinical isolates

\begin{tabular}{|c|c|c|c|c|c|c|}
\hline \multirow[b]{2}{*}{ Name of isolates } & \multicolumn{6}{|l|}{ Sources } \\
\hline & $\begin{array}{l}\text { Intra } \\
\text { abdominal }\end{array}$ & Abscess & $\begin{array}{l}\text { Bone and } \\
\text { joint infections }\end{array}$ & Total (53) & $\begin{array}{l}\text { Metronidazole } \\
\text { resistant isolates by } \\
\text { phenotypic method }(\%)\end{array}$ & $\begin{array}{l}\text { Metronidazole } \\
\text { resistant isolates } \\
\text { by PCR }(\%) \\
\end{array}$ \\
\hline Bacteroides fragilis & 9 & 7 & 2 & 18 & $10(55.5)$ & $7(38.9)$ \\
\hline Escherichia coli & 9 & 8 & 0 & 17 & $4(23.5)$ & $2(11.7)$ \\
\hline Staphylococcus aureus & 0 & 5 & 6 & 11 & $2(18.2)$ & $1(9.1)$ \\
\hline Yersinia enterocolitica & 7 & 0 & 0 & 7 & $5(71.4)$ & $3(42.8)$ \\
\hline Total & 25 & 20 & 8 & 53 & 21(39.6) & $13(24.5)$ \\
\hline
\end{tabular}


Table 2. Effect of drugs on nitro-reductase activity of nim positive isolates

$\%$ inhibition of nitro-reductase activity

\begin{tabular}{llllll} 
& \% inhibition of nitro-reductase activity & & \\
& - & & \\
Name of drugs & Bacteroides fragilis & Escherichia coli & Staphylococcus aureus & Yersinia enterocolitica & B. fragilis 638R \\
\hline $\begin{array}{l}\text { Mebatic (Ofloxacin+ } \\
\text { Ornidazole+VRP006) }\end{array}$ & $86.3 \pm 6.5$ & $87.5 \pm 7.3$ & $86.8 \pm 8.1$ & $89.3 \pm 8.5$ & $88.3 \pm 7.8$ \\
Ornidazole & $10.1 \pm 1.2$ & $8.4 \pm 0.9$ & $9.3 \pm 1.1$ & $9.4 \pm 0.9$ & $8.1 \pm 0.9$ \\
Ofloxacin & $9.8 \pm 1.1$ & $8.6 \pm 1.0$ & $8.5 \pm 0.9$ & $8.7 \pm 1.0$ & $8.4 \pm 0.8$ \\
Metronidazole & $8.8 \pm 1.3$ & $8.6 \pm 0.9$ & $9.2 \pm 1.1$ & $8.6 \pm 0.9$ & $8.7 \pm 0.7$ \\
Ciprofloxacin & $7.4 \pm 0.8$ & $7.5 \pm 0.8$ & $8.5 \pm 1.0$ & $10.3 \pm 0.9$ & $7.9 \pm 8.3$ \\
\hline
\end{tabular}

Table 3. Minimum inhibitory concentration test of drugs against anaerobic strains

\begin{tabular}{|c|c|c|c|c|c|c|}
\hline \multirow[b]{2}{*}{ Name of drugs } & \multicolumn{6}{|c|}{$\mathrm{MIC}(\mu \mathrm{g} / \mathrm{mL})$} \\
\hline & $\begin{array}{l}\text { Bacteroides } \\
\text { fragilis }\end{array}$ & $\begin{array}{l}\text { Escherichia } \\
\text { coli }\end{array}$ & $\begin{array}{l}\text { Staphylococcus } \\
\text { Aureus }\end{array}$ & $\begin{array}{l}\text { Yersinia } \\
\text { enterocolitica }\end{array}$ & $\begin{array}{l}\text { B. fragilis } \\
\text { ATCC25285 }\end{array}$ & B. fragilis $638 R$ \\
\hline $\begin{array}{l}\text { Mebatic (Ofloxacin } \\
\text { +Ornidazole+VRP006) }\end{array}$ & $0.25-1.0$ & $0.125-1.0$ & $0.25-1.0$ & $0.125-1.0$ & 0.13 & 0.25 \\
\hline Ornidazole & $8.0-64$ & $8.0-128$ & $8.0-64$ & $8.0-128$ & 2.00 & 16.0 \\
\hline Ofloxacin & $8.0-128$ & $1.0-8.0$ & $1.0-8.0$ & $1.0-8.0$ & 1.00 & 16.0 \\
\hline Metronidazole & $8.0-64$ & $16-28$ & $16-64$ & $16-128$ & 0.25 & 16.0 \\
\hline Ciprofloxacin & $8.0-128.0$ & $2.0-6$ & $2.0-16$ & $2.0-32.0$ & 2.00 & 32.0 \\
\hline
\end{tabular}

Table 4. Antimicrobial susceptibility of drugs against anaerobic strains

\begin{tabular}{|c|c|c|c|c|c|c|}
\hline \multirow[b]{2}{*}{ Name of drugs } & \multicolumn{6}{|c|}{ Zone of inhibition $(\mathrm{mm})$} \\
\hline & $\begin{array}{l}\text { Bacteroides } \\
\text { Fragilis }\end{array}$ & $\begin{array}{l}\text { Escherichia } \\
\text { coli }\end{array}$ & $\begin{array}{l}\text { Staphylococcus } \\
\text { aureus }\end{array}$ & $\begin{array}{l}\text { Yersinia } \\
\text { enterocolitica }\end{array}$ & $\begin{array}{l}\text { B. fragilis } \\
\text { ATCC } 25285\end{array}$ & B. fragilis $638 R$ \\
\hline $\begin{array}{l}\text { Mebatic Ofloxacin } \\
\text { +Ornidazole +VRP006) } \\
(5: 12.5 \mu \mathrm{g})\end{array}$ & $22.7 \pm 2.1$ & $26.5 \pm 2.4$ & $24.7 \pm 2.3$ & $25.9 \pm 2.2$ & $29.2 \pm 2.4$ & $26.3 \pm 2.3$ \\
\hline Ornidazole $(30 \mu \mathrm{g})$ & $15.5 \pm 1.1$ & No zone & No zone & No zone & $20.4 \pm 1.9$ & $10.5 \pm 1.6$ \\
\hline Ofloxacin $(5 \mu \mathrm{g})$ & No zone & $19.4 \pm 1.8$ & $18.2 \pm 1.2$ & $17.4 \pm 1.5$ & $22.4 \pm 2.2$ & $11.2 \pm 1.3$ \\
\hline Metronidazole $(30 \mu \mathrm{g})$ & $11.2 \pm 1.1$ & $8.4 \pm 1.0$ & $7.2 \pm 0.8$ & $7.4 \pm 1.0$ & $22.2 \pm 2.1$ & $8.2 \pm 1.0$ \\
\hline Ciprofloxacin $(5 \mu \mathrm{g})$ & $8.6 \pm 1.2$ & $14.6 \pm 1.1$ & $13.5 \pm 1.2$ & $12.1 \pm 1.0$ & $21.6 \pm 1.7$ & $12.5 \pm 1.1$ \\
\hline
\end{tabular}

$\mathrm{S}=\geq 21, \mathrm{I}=16-20, \mathrm{R}=\leq 15$

\subsection{AST}

The zones of inhibition were calculated in millimetre for all strains and presented in the Table 4. Mebatic was found to be most effective against all clinical isolates as evident by zone of inhibition values between 22 to $26 \mathrm{~mm}$. Other tested drugs including ofloxacin, ornidazole, metronidazole and ciprofloxacin displayed intermediate to resistant profile against all of the clinical isolates.

\section{DISCUSSION}

The implications of anaerobic microbes in the human infections is well known. The infections caused by anaerobic bacteria are some of the most important causes of morbidly and mortality in developing countries (Akhi et al., 2013). The development of resistance to metronidazole leading to treatment failure during the course of metronidazole therapy in a patient has been reported (Buta et al., 2010; Soki et al., 2013). Numerous studies have demonstrated the incidence of metronidazole resistance in recent years (Alauzet et al., 2010; Lynch et al., 2013; Abdollahi et al., 2011). In a study conducted by Datta et al. (2005) reported that $85 \%$ strains of Helicobacter pylori were resistant to metronidazole. In other previous studies, metronidazole resistance in Bacteroides spp. has been noted to be varied from 5 to $>15 \%$ (Gal and Brazier, 2004).

Our PCR data revealed that $13(24.5 \%)$ isolates were metronidazole resistant suggesting nim genes are quite 
common in metronidazole resistant clinical isolates. Intrestingly, our results showed that in addition to $B$. fragilis, nim gene was detected across a number of facultative anaerobes specieses, E. coli, S. aureus and $Y$. enterocolitica which indicates transferability of nimA gene from one species to another in anaerobic environments. It has also been reported earlier that metronidazole resistance could be a consequence of the activation of nim gene as a result of point mutation (Gal and Brazier, 2004). We observed that the metronidazole resistant isolates were mainly found in abscess $53.8 \%$ (7/13) followed by intra-abdominal $38.5 \%(5 / 13)$ and bone and joint infection $7.7 \%(1 / 13)$. This study is hospital based and does not reflect the prevalence or incidence of metronidazole resistance in the community. Leiros et al. (2010) studied the hydrophobicity profile of the nim gene products and reported that it decreases penetration of metronidazole into the cells. It has also been noted that the nim genes encode a 5-nitroimidazole reductase that converts 5nitroimidazole to its non-toxic amino derivative, thus preventing the accumulation of toxic nitroradicals (Lofmark et al., 2010).

In our study, Mebatic was found to be most efficacious antibacterial agent against metronidazole resistant organisms. The enhanced antimicrobial efficacy of Mebatic against these isolates may be due to the synergistic effect of ofloxacin and ornidazole along with a non antibiotic adjuvant VRP006 (disclosed by Venus Remedies on request) which enhanced the penetration of the drug inside the bacterial cells and inhibits the nitro reductase activity thus prevents the conversion of non toxic form of the drug.

It has been reported that metronidazole-resistant and susceptible strains of $B$. fragilis became more virulent following exposure to low doses of metronidazole. Probably low concentration of Metronidazole may paved the way for the development of either non-stable phenotypes or permanently resistant mutants (Diniz et al., 2003), therefore, rapid identification of Metronidazole resistance is essential for early initiation of appropriate antimicrobial therapy and to limit the inappropriate use of antibacterial agents.

\section{CONCLUSION}

In conclusion, from the above results, it is evident that Mebatic has synergisticin vitro antibacterial activity as compared to other drugs in Metronidazole resistant isolates thus can be a potent antibacterial agent for the treatment of infections caused by Metronidazole resistant organisms.

\section{ACKNOWLEDGMENT}

Researchers are thankful to Emerging Antimicrobial Resistance Society (EARS), Chandigadh, India for providing assistance to carry out this study. We are also thankful to all centres for providing clinical isolates.

\section{REFERENCES}

Abdollahi, H., M. Savari, M.J. Zahedi, M.S. Darvish and H.M. Abasi, 2011. A study of rdxA gene deletion in metronidazole resistant and sensitive Helicobacter pylori isolates in Kerman, Iran. Jundishapur J. Microbiol., 4: 99-104.

Akhi, M.T., M. Shirinzadeh, R. Ghotaslou, M.H. Sorous and T. Pirzadeh et al., 2013. Determination of antibiotic sensitivity of Bacteroid fragilis isolated from patients and healthy individuals in Imam Reza Center of Medical Teaching and Treatment-Tabriz. Jundishapur J. Microbiol., 6: e7880-e7880. DOI: $10.5812 / \mathrm{jjm} .7880$

Alauzet, C., F. Mory, C. Teyssier, H. Hallage and J.P. Carlier et al., 2010. Metronidazole resistance in Prevotella spp. and description of a new nim gene in Prevotella baroniae. Antimicrob. Agents Chemother., 54: 60-64. DOI: 10.1128/AAC.01003-09

Atashpaz, S., S. Khani, A. Barzegari, J. Barar and S.Z. Vahed et al., 2010. A robust universal method for extraction of genomic DNA from bacterial species. Mikrobiology, 79: 562-566. PMID: 21058509

Boente, R.F., L.Q. Ferreira, L.S. Falcao, K.R. Miranda and P.L. Guimaraes et al., 2010. Detection of resistance genes and susceptibility patterns in Bacteroides and Parabacteroides strains. Anaerobe, 16:190-4. DOI: 10.1016/j.anaerobe.2010.02.003

Brook, I., 2010. The role of anaerobic bacteria in bacteremia. Anaerobe, 16: 183-189. DOI: 10.1016/j.anaerobe.2009.12.001

Brook, I., 2008. Microbiology and management of abdominal infections. Digestive Diseases Sci., 53: 2585-9. DOI: 10.1007/s10620-007-0194-6

Buta, N., N.F. Tanih and R.N. Ddip, 2010. Increasing trend of metronidazole resistance in the treatment of Helicobacter pylori infection: A global challeng. Afrcan J. Biotechnol., 9: 1115-1121. 
CLSI, 2013. Clinical Laboratory Standards Institute Antimicrobial Susceptibility Testing. Institute for Drug Resistance.

Chaudhary, M., G.K. Naidu, S. kumar and A. Payasi, 2012. Comparative antibacterial activity activity of a novel antibiotic: Etimicin sulphate and other aminoglycosides. World J. Microbiol. Biotechnol, 28: 3365-3371. DOI: 10.1007/s11274-012-1148-5

Cohen, S.H., D.N. Gerding, S. Johnson, C.P. Kelly and V.G. Loo et al., 2010. Clinical practice guidelines for clostridium difficile Infection in Adults: 2010 Update by the Society for Healthcare Epidemiology of America (SHEA) and the Infectious Diseases Society of America (IDSA). Infect. Controll Hospital Epidemiol., 31: 431-455. DOI: 10.1086/651706

Datta, S., S. Chattopadhyay, R. Patra, R. De and T. Ramamurthy et al., 2005. Most Helicobacter pylori strains of Kolkata in India are resistant to metronidazole but susceptible to other drugs commonly used for eradication and ulcer therapy. Alimen. Pharmacol. Therapy, 22: 51-57. DOI: 10.1111/j.1365-2036.2005.02533.x

Diniz, C.G., R.M. Arantes and D.C. Cara, 2003. Enhanced pathogenicity of susceptible strains of the Bacteroides fragilis group subjected to low doses of metronidazole. Microb. Infect., 5: 19-26. DOI: 10.1016/S1286-4579(02)00052-7

Gaetti-Jardim, E.C., A.C. Marqueti, L.P. Faverani and E. G.J. Junior, 2010. Antimicrobial resistance of aerobes and facultative anaerobes isolated from the oral cavity. J. Appl. Oral Sci. 18:551-559. PMID: 21308284

Guss, A.M., G. Roeselers, I.L.G. Newton, C.R. Young, V. Klepac-Ceraj, S. Lory and C.M. Cavanaugh, 2011. Phylogenetic and metabolic diversity of bacteria associated with cystic fibrosis. ISME J., 5: 20-29. DOI:10.1038/ismej.2010.88

Gal, M. and J.S. Brazier, 2004. Metronidazole resistance in Bacteroides spp. carrying nim genes and the selection of slow-growing metronidazoleresistant mutants. Antimicrobial J. Chemotherapy, 54: 109-116. DOI: 10.1093/jac/dkh296

Hartmeyer, G.N., J. Soki, E. Nagy and U.S. Justesen, 2012. Multidrug-resistant Bacteroides fragilis group on the rise in Europe. J. Med. Microbiol., 61: 1784-1788. DOI: 10.1099/jmm.0.049825-0

Levinson, W., 2010. Review of Medical Microbiology and Immunology. 11th Edn., McGraw-Hill Companies, Incorporated, ISBN-10: 0071700285, pp: 640 .
Leiros, H.K., B.O. Brandsdal and S.M. McSweeney 2010. Biophysical characterization and mutational analysis of the antibiotic resistance protein NimA from Deinococcus radiodurans. Biochim. Biophys. Acta., 1804: 967-976. DOI: 10.1016/j.bbapap.2010.01.010 PMID: 20096385

Lofmark, S., C. Edlund and C.E. Nord, 2010. Metronidazole is still the drug of choice for treatment of anaerobic infections. Clin. Infect. Diseases, 1: 16-23. PMID: 20067388, DOI: 10.1086/647939

Lynch, T., P. Chong, J. Zhang, R. Hizon and T. Du et al. 2013. Characterization of a stable, metronidazoleresistant Clostridium difficile clinical isolate. PLoS ONE, 8: e53757-e53757. DOI: 10.1371/journal.pone.0053757

Merino, V.R., V. Nakano, C. Liu, Y. Song and S.M. Finegold et al., 2011. Quantitative detection of enterotoxigenic Bacteroides fragilis subtypes isolated from children with and without diarrhea. J. Clin. Microbiol., 49: 416-418. DOI: 10.1128/JCM.01556-10

Nakano, V., A.N. Silva, V.R.C. Merino, H.M. Wexler and M.J. Avila-Compos, 2011. Antimicrobial resistance and prevalence of resistance genes in intestinal Bacteroidales strains. Clinics, 66: 543-547. DOI: 10.1590/S1807-59322011000400004

Nagy, E., E. Urban and C.E. Nord, 2011. Antimicrobial susceptibility of Bacteroides fragilis group isolates in Europe: 20 years of experience. Clin. Microb. Infect., 17:371-379. DOI: 10.1111/j.14690691.2010.03256.x, PMID: 20456453

Pal, D., S. Banerjee, J. Cui, A. Schwartz, S.K. Ghosh and J. Samuelson, 2009. Giardia, entamoeba and Trichomonas enzymes activate metronidazole (nitroreductases) and inactivate metronidazole (nitroimidazole reductases). Antimicrobial Agents Chemotherapay, 53: 458-458. DOI: 10.1128/AAC.00909-08

Pumbwe, L., M. Curzon and H.M. Wexler, 2008. Rapid multiplex PCR assay for simult aneous detection of major antibiotic resistance determinants in clinical isolates of Bacteroides fragilis. J. Rapid Meth. Automat. Microbiol., 16: 381-393. DOI: 10.1111/j.1745-4581.2008.00143.x

Schapiro, J.M., R. Gupta, E. Stefansson, F.C. Fang and A.P. Limaye, 2004. Isolation of metronidazoleresistant Bacteroides fragilis carrying the nimA nitroreductase Gene from a patient in Washington state. J. Clin. Microbiol., 42: 4127-4129. DOI: 10.1128/JCM.42.9.4127-4129.2004 
Steffens, L.S., S. Nicholson, L.V. Paul, C.E. Nord and S. Patrick, 2010. Bacteroides fragilis RecA protein overexpression causes resistance to metronidazole. Res. Microbiol., 161: 346-354. PMID: $20435137 . \quad$ DOI: 10.1016/j.resmic.2010.04.003

Snydman, D.R., N.V. Jacobus and L.A. McDermott, Y. Golan, D.W. Hecht et al., 2010. Lessons learned from the anaerobe survey: Historical perspective and review of the most recent data (2005-2007). Clin. Infect. Dis., 50: 26-33. PMID: 20067390. DOI: $10.1086 / 647940$
Soki, J., Z. Eitel, E. Urban and E. Nagy, 2013. ESCMID study group on antimicrobial resistance in anaerobic bacteria. Molecular analysis of the carbapenem and metronidazole resistance mechanisms of Bacteroides strains reported in a Europe-wide antibiotic resistance survey. Int. J. Antimicrob. Agents, 41: 122-125. PMID: 23158541

Verma, A.K., R. Verma, V. Ahuja and J. Paul, 2012. Real-time analysis of gut flora in Entamoeba histolytica infected patients of Northern India. BMC Microbiol., 12: 183-183. DOI: $10.1186 / 1471-2180-12-183$ 